\title{
Sınıf Öğretmenlerinin Mülteci Öğrencilere Yönelik Tutumlarının Çeşitli Değişkenler Açısından İncelenmesi ${ }^{*}$ \\ Investigation Attitudes towards Refugee Students of Class Teachers' in Terms of Several Variables \\ Halil İbrahim SAĞLAM**
}

\begin{abstract}
Öz. Bu araştırmanın amacı, sınıf öğretmenlerinin mülteci öğrencilere yönelik tutumlarını incelemektir. Bu amaçla üç alt boyuttan oluşan 24 maddelik Mülteci Öğrenci Tutum Ölçeği (MÖTÖ) geliştirilmiştir. Cronbach Alpha güvenirlik katsayısı .91 olan ölçeğin alt boyutları "iletişim", "uyum", "yeterlik"tir. Ölçek, 2016-2017 eğitim öğretim yılında Sakarya ilinde çalışan 267'si kadın (\%53), 234'ü (\%47) erkek olmak üzere toplam 501 sınıf öğretmenine uygulanmışır. Kolmogorov-Smirnov testi sonucunda dağılımların normal olduğu sonucuna ulaşılmıştır. Cinsiyet, sınıfta mülteci öğrenci olup olmama durumu için t-testi; okul çevresinin bulunduğu sosyoekonomik düzey değişenleri için tek yönlü varyans analizi yapılmıştır. Araştırma sonucunda öğretmenlerin cinsiyetlerine göre mülteci öğrencilere yönelik tutumlarının "yeterlik" boyutunda erkek öğretmenler lehine; okulun bulunduğu sosyoekonomik çevreye göre orta sosyoekonomik çevre lehine; sınıflarında mülteci öğrenci olup olmama durumuna göre "iletişim" boyutu hariç sınıflarında mülteci öğrenci bulunan öğretmenler lehine anlamlı bir şekilde farklılaştığı bulunmuştur.
\end{abstract}

Anahtar Kelimeler: Mülteci, mülteci öğrenci, sınıf öğretmeni, ilkokul.

Abstract. The aim of this study is to examine the attitudes of classroom teachers towards refugee students. For this purpose, "Refugee Student Attitude Scale (RSAS)" which consists of three sub-dimensions and 24 items were developed. Cronbach Alpha reliability coefficient was found .91 and the subdimensions of the scale were "communication", "adaptation", "efficiency". The scale was applied to the 501 class teachers. 267 of them were female (53\%) and 234 of them were $(47 \%)$ male who work in the province of Sakarya in the academic year 2016-2017. Kolmogorov-Smirnov test showed that independent variables have a normal distribution. T-test was conducted for gender and whether a refugee student exists in class or not; one-way-Anova was conducted for socioeconomic level changes of seniority and school environment variables. As a result of the research, there was significant difference in the teachers' attitudes towards the refugee students regarding their genders in favor of male teachers in the "competence" dimension. Moreover, there was significant difference in the teachers' attitudes towards the refugee students with respect to the socioeconomic environment in which the school is located in favor of the medium socioeconomic environment. Finally, there was significant difference in the teachers' attitudes towards the refugee students according to whether a refugee student exists in class or not in favor of teachers with refugee students in their class in all sub-dimensions except for "communication" dimension.
Toplumsal Mesaj. Savaşlar nedeniyle özellikle Suriyeli mülteciler 2011 Türkiye'ye sığınmaktadır. Bu durum öğrenim çağı nüfusunun eğitimdeki sürdürülebilirliğini zorlaştırmaktadır. araştırma ile ilkokulda görev yapan öğretmenlerin mülteci öğrencilere yönelik tutumları incelenmiştir. Dil ve kültürel problemler nedeniyle Suriyeli öğrencilerin eğitiminde yeterli düzeye ulaşılamadığı belirlenmiştir.

Public Interest Statement. Especially, Syrian refugees have been taking refuge in Turkey since 2011 due to the wars in their region. This situation makes the sustainability of the education of this population more difficult. This research examines the attitudes of primary school teachers towards refugee students. In the education of the Syrian students, the teachers did not feel qualified enough to teach these students due to the language and cultural problems.

Keywords: Refugee, Refugee student, classroom teacher, primary school.

\footnotetext{
* Bu çalışma birinci yazarın danışmanlığındaki ikinci yazarın yükseklisans tezinden üretilmiştir.

** Doç. Dr., Sakarya Üniversitesi Eğitim Fakültesi Öğretim Üyesi, Sakarya. hsaglam@sakarya.edu.tr

*** Sakarya Üniversitesi Eğitim Bilimleri Enstitüsü Yüksek Lisans Öğrencisi, Sakarya
} 


\section{GíRiş}

Insanların tarih boyunca farklı nedenlerle farklı coğrafyalara göç ettikleri bilinmektedir. Göçler toplumların siyasal, sosyal, ekonomik ve kültürel olarak etkilenmelerinde önemli rol oynar (Ünal, 2014; Apak, 2014). “Pek çok güçlüğü bünyesinde barındıran göç hareketleri, süreç içerisinde hem göç eden hem de göç alan toplumlarda kültürel değişimlere neden olmaktadır. Bununla birlikte, zorunlu göçlerde mülteci veya sı̆̆ınmacı olmanın toplumsal dinamikleri ekonomik nedenli göçlerden farklılık göstermektedir. Silahlı çatışma ve şiddet olayları, yaşamlarını ülkelerinde sürdürülemez kıldığı için yurtlarını ya da içinde yaşadıkları toplumları terk etmek zorunda kalan sığınmacıların çoğu ilk sığınma yeri olan komşu ülkelerde kalmayı tercih etmektedirler" (Zolberg ve Benda, 2001: 408). Dünya genelinde göç eden kitlelere bakıldığında, göç edenlerin en önemli kısmını ekonomik amaçlı göçmenlerin oluşturduğu görülmektedir. Bunu sırasıyla sığınmacılar, mülteciler ve ülke içerisinde yerinden edilmiş kişiler takip etmektedir. 2015 yılı Birleşmiş Milletler [BM] verilerine göre dünya genelinde sığınmacı, mülteci ve ülke içi yerinden edilmiş kişilerin sayısı 60 milyonu aşmıştır (Deniz ve Yıldız, 2016). Tarih boyunca en fazla göçmen akınına uğrayan ülkelerden biri de coğrafi konumu itibariyle Türkiye olmuştur (Kıratlı, 2011). 1970'li yılların sonundan itibaren Türkiye'ye, özellikle sınır komşusu olduğu ülkelerden sığınmacı, mülteci, transit göçmen ve kaçak iş̧̧i gibi uluslararası göçler olmuştur (Güneş, 2013). Türkiye, Suriye kaynaklı yeni bir uluslararası göç hareketliliğinin etkisinde bulunmaktadır (Kıratlı, 2011). 29 Nisan 2011'de Suriye'den Türkiye'ye sığınan 252 kişilik ilk sığınmacı grubuyla başlayan zorunlu göç dalgası, çatışmaların büyümesiyle Suriye'den kaçan milyonlarca insanı yerinden eden kitlesel bir göç hareketine dönüşmüştür (Akşit, Bozok ve Bozok, 2015). Türkiye, Suriyeli mültecilere yönelik açık kapı politikası uygulayarak onlara geçici koruma statüsü tanımıştır. Türkiye bu süreçte kendine sığınanı imkânlar ölçüsünde en iyi şekilde misafir etmeye özen göstermiştir (Türkiye Büyük Millet Meclisi İnsan Hakları İnceleme Komisyonu [TВMмініK], 2013). Bu durum, Türkiye'ye sığınan Suriyeli mülteci sayısının günden güne artmasına zemin hazırlamıştır (Kılcan, Çepni ve Kılınç, 2017).

Bir ülkede sığınma hakkı verilen kişiye mülteci (Tunç, 2015), bir ülkeye mülteci olarak kabul edilmek isteyen ve mültecilik statüsüne ilişkin yaptıkları başvurunun sonucunu bekleyen kişiye de sığınmacı (Akt., Tunç, 2015) denilmektedir. Mülteciler ve sığınmacılar uluslararası sözleşmelerin ve gittikleri ülkelerin yasalarının izin verdiği ölçüde bazı haklardan faydalanabilmektedir. Yabancılar ve Uluslararası Koruma Kanunu [YUKK] yürürlüğe girene kadar, Avrupa'dan gelen ve iltica nedeni olan kişiler Türkiye'de mülteci; Avrupa dışından gelen ve iltica nedeni olan kişiler ise sığınmacı olarak adlandırmaktaydı. Yabancılar ve Uluslararası Koruma Kanunu'nun yürürlüğe girmesiyle birlikte, Avrupa'dan gelenler mülteci olarak adlandırılmaya devam ederken, Avrupa dışından gelenler şartlı mülteci olarak adlandırılmaya başlanmıştır (Körükmez ve Südaş, 2015). Suriye'de meydana gelen çatışma ve zorunlu göç sonucu yaşanan olaylardan en çok çocuklar etkilenmiştir. Çocuklar maruz kaldıkları psikolojik travmanın yanı sıra, toplumsal ayrımcılık, ekonomik ve cinsel sömürü, çocuk evlilikleri dâhil olmak üzere çok çeşitli risklerle karşı karşıya gelmiş, ciddi biçimde savunmasız duruma düşmüştür (Birleşmiş Milletler Uluslararası Çocuklara Yardım Fonu [UNICEF], 2016). Gelişme çă̆ında olan çocukların, karşılaştıkları olumsuz durumlardan etkilenmeleri ve bu etkilerin yaşamlarında derin izler bırakması kaçınılmazdır (Beter, 2006). UNICEF'in Ekim 2016 tarihli verilerine göre Türkiye'ye göç eden 2.764 .500 kayıtlı Suriyelinin yaklaşık \%45'ini 0-18 yaş aralığındaki çocuklar oluşturmaktadır. Bunlar arasında okul çağındaki Suriyeli çocuk sayısı 860.000 'dir. 370.000 çocuğun ise okula gidemediği tahmin edilmektedir. Mülteciler içerisinde çocukların büyük bir yekûn teşkil etmesi, öğrenim çağındaki çocuklara, bu çocukların eğitimine dikkat çekilmesini zorunlu hale getirmektedir.

Insan hayatında eğitimin, eğitimin temeli sayılabilecek ilkokulun önemli yeri vardır. Bu bakımdan yaşamlarını Türkiye'de devam ettiren ve ilkokul çağında bulunan mülteci öğrencilerin eğitimi büyük önem arz etmektedir. Mülteci öğrencilerin sınıflarına uyum sağlayabilmeleri, yaşadıkları olumsuzluklardan kurtulabilmeleri öğretmenlerinin yaklaşımlarıyla, tutumlarıyla yakından ilgilidir. $\mathrm{Bu}$ anlamda ilkokullarda görev yapan sınıf öğretmenlerine önemli görev ve sorumluluklar 
düşmektedir. Temel bilgi ve becerilerin öğrenildiği, karmaşık öğrenmelerin alt yapısının oluşturulduğu bu dönemde, büyük badireler geçirmiş mülteci öğrencilerin yaşama tutunabilmeleri, yaşadıkları ülkeye sevgi besleyebilmeleri sınıf öğretmenlerinin yaklaşımlarıyla yakından ilişkilidir.

Literatürde mülteci öğrencileri konu alan çalışmalar (Balkar, Şahin ve Işıklı Babahan, 2016; Baltacı, 2014; Börü ve Boyacı, 2016; Er ve Bayındır, 2015; Kılcan, Çepni ve Kılınç, 2017; Mercan Uzun ve Bütün, 2016; Nar, 2008; Özer, Komsuoğlu ve Ateşok, 2016) bulunmaktadır. Balkar, Şahin ve Işıklı Babahan (2016) Suriyeli öğretmenlerin ve Geçici Eğitim Merkezi (GEM) koordinatörlerinin yönetim süreçlerinde karşılaştıkları sorunları; Baltacı (2014) Türkiye'den Kuzey Kıbrıs'a göç eden göçmen öğrencilerin akademik başarılarını etkileyen etmenleri; Börü ve Boyacı (2016) göçmenlerin eğitim öğretim ortamlarında karşılaştıkları sorunları; Er ve Bayındır (2015) ilkokula giden mülteci çocuklara yönelik sınıf öğretmenlerinin pedagojik yaklaşımlarını; Kılcan, Çepni ve Kılınç (2017), mülteci ortaokul öğrencilerine yönelik tutum ölçeği geliştirme çalışmasını; Mercan Uzun ve Bütün (2016) okul öncesi eğitim kurumlarına devam eden sığınmacı çocukların uyum sağlama sürecinde karşılaştıkları sorunları; Nar (2008), göçün eğitim öğretime etkilerini; Özer, Komsuoğlu ve Ateşok (2016) Suriyeli çocukların eğitimi ile ilgili kamu politikaları inşa sürecindeki sorunları ve çözüm önerilerini ele almışlardır. Sınıf öğretmenlerinin mülteci öğrencilere yönelik tutumlarını konu alan bir çalışmaya rastlanmamış olması nedeniyle bu araştırmanın söz konusu çalışmalardan farklı olduğu düşünülmüş ve bu nedenle, sınıf öğretmenlerinin mülteci öğrencilere yönelik tutumlarının incelenmesi araştırmanın temel amacı olarak belirlenmiştir. Ayrıca sınıf öğretmenlerinin mülteci öğrencilere yönelik tutumlarının cinsiyet, çalıştıkları okulun bulunduğu sosyoekonomik çevre, sınıflarında mülteci öğrenci olup olmama durumlarına göre farklılaşıp farklılaşmadığının belirlenmesi amaçlanmıştır.

\section{YÖNTEM}

\subsection{Araştırmanın Modeli}

$\mathrm{Bu}$ araştırma, tarama modellerinden karşılaştırma türü ilişkisel tarama ile yapılmıştır. Tarama modelleri, geçmişte ya da şu anda olan bir durumu var olduğu şekliyle betimlemeyi amaçlayan araştırma modelleridir. Karşılaştırma türü ilişkisel tarama modellerinde, en az iki değişken bulunup bunlardan birine göre gruplar oluşturularak diğer değişkene göre aralarında bir farklılaşma olup olmadığı incelenir (Karasar, 2005). Bu araştırmada da, sınıf öğretmenlerinin mülteci öğrencilere yönelik yönelik tutumları çeşitli değişkenler açısından incelenmiştir.

\section{2 Çalışma Grubu}

Bu araştırmanın çalışma grubunu, 2016-2017 eğitim öğretim yılında Sakarya ilinde görev yapmakta olan 267'si (\%53) kadın, 234'ü (\%47) erkek olmak üzere toplam 501 sınıf öğretmeni oluşturmaktadır. Araştırmaya katılan öğretmenlerin \%26'sının alt, \%72'sinin orta, \%2'sinin üst sosyoekonomik çevrelerdeki okullarda çalıştıkları; \%67'sinin sınıfında mülteci öğrenci olduğu, \%33'ünün sınıfında mülteci öğrenci bulunmadığı belirlenmiştir. Sakarya ilinde bulunan ilkokullar merkeze yakınlığına göre sosyoekonomik düzeyi alt, orta ve yüksek şeklinde gruplandırılmış ve bu üç gruptan seçkisiz olarak çalışma grubu oluşturulmuştur.

\subsection{Veri Toplama Aracı}

Araştırmacılar tarafından literatür taraması yapılmış ve 45 maddelik bir madde havuzu oluşturulmuştur. Havuzdaki maddeler rehberlik ve psikolojik danışmanlık, sınıf eğitimi alanlarında uzman 2 öğretim üyesinin değerlendirmeleri ve önerileri doğrultusunda incelenerek, maddelerde gerekli düzeltmeler yapılmış, çıkartılması istenen 5 madde ölçekten çıkartılmıştır. Yapı geçerliği ve güvenirlik çalışmaları için ölçek çalışma grubuna uygulanmıştır. Bu uygulamadan elde edilen veriler doğrultusunda yapı geçerliği için "açımlayıcı faktör analizi" uygulanmıştır (Büyüköztürk, 2009). Faktör analizi sonucunda faktör yükleri düşük çıktığı, birden çok faktörde eşit faktör yüküne sahip olduğu için 16 madde ölçekten çıkarılmış ve 24 maddelik ölçeğe yeniden faktör analizi yapılmıştır. Faktör analizi yapabilmek için öncelikle KMO ve Bartlett Sphericity testi değerlerine bakılmış ve 
KMO değeri .91 olarak bulunmuştur. Ayrıca verilerin çok değişkenli normal dağılımdan gelip gelmediğini kontrol etmek için kullanılan Barlett Küresellik testine bakılmış ve anlamlı ( $\chi 2=$ 5475.902; p<.000) farklılık gösterdiği için ölçeğin faktör analizinin yapılmasının uygun olduğuna karar verilmiştir (Büyüköztürk, 2009). Faktör analizi sonucunda ölçeğin 24 maddeden oluşan üç boyutlu bir yapıya sahip olduğu bulunmuş; birinci boyutun "iletişim", ikinci boyutun "uyum" ve üçüncü boyutun "yeterlik" şeklinde adlandırımıştır. Örnek olarak "Mülteci öğrencilere önyargısız yaklaşırım" maddesi birinci boyutta yer alırken, "Öğrenciler mülteci öğrencilerle birlikte olmaktan memnundurlar" maddesi ikinci boyutta ve "Mülteci öğrencilerin eğitiminde yeterli olduğumu düşünürüm" maddesi üçüncü boyutta yer almaktadır. Ölçeği oluşturan maddelere ilişkin faktör yük değerleri birinci boyut için .45 ile .75 arasında, ikinci boyut için .40 ile .79 arasında ve üçüncü boyut için .60 ile .83 arasında değişmektedir. Toplamda açıklanan \%53.61'lik varyansın \%21.81'i birinci, \%19.95'i ikinci ve \%11.85'i üçüncü boyut tarafından açıklanmaktadır. Ölçekteki tüm maddeler olumlu puanlanmaktadır ve cevaplayıcıya dörtlü dereceleme imkânı vermektedir. Ölçekten alınabilecek minimum puan 24 ve maksimum puan 96'dır. Puanın yüksekliği, mülteci öğrencilere yönelik tutumun pozitifliğine işaret etmektedir. Mülteci Öğrenci Tutum Ölçeği'nin güvenirliğini belirlemek için iç tutarlılık katsayıları incelenmiştir. Ölçeğin güvenirliğine ilişkin olarak iç tutarlıklık katsayısı (Alpha) .91 olarak hesaplanmıştır. Bu değer ölçeği oluşturan maddelerin birbirleriyle tutarlı olduğunu göstermektedir. Her bir alt boyut için ayrı ayrı iç tutarlılık güvenirlik katsayıları da hesaplanmıştır. Birinci alt boyuta ilişkin güvenirlik katsayı .88, ikinci alt boyuta ilişkin güvenirlik katsayısı .88 ve üçüncü alt boyuta ilişkin güvenirlik katsayısı .80 olarak hesaplanmıştır.

\subsection{Verilerin Toplanması}

Araştırma için geliştirilen Mülteci Öğrenci Tutum Ölçeği (MÖTÖ) Sakarya ilinde bulunan toplam 49 ilköğretim okuluna araştırmacılar tarafından getirilmiştir. Okul yönetimiyle görüşüldükten sonra öğretmenlere uygulamıştır. Dağıtılan 570 veri toplama aracından 550 tanesi geri dönmüştür. Veri toplama araçlarından 49'u gerek boş bırakıldığından gerekse amaca uygun olarak doldurulmadığı belirlendiğinden değerlendirme dışında tutulmuştur. Değerlendirmeler 501 veri toplama aracı üzerinden yapılmıştır.

\subsection{Verilerin Analizi}

Verilerin analizine başlanmadan önce veri toplama araçları tek tek kontrol edilerek sıralanmış, veri toplama araçları yoluyla elde edilen veriler tanımlanmış ve SPSS programına yüklenmiştir. Veri toplama aracının geçerlik ve güvenirlik analizlerinden sonra veriler araştırmanın alt problemlerine göre analiz edilmiştir. Elde edilen verilere hangi testlerin uygulanacağını belirlemek amacıyla değişkenlerin dağılımının normalliği Kolmogorov-Smirnov testi ile incelenmiştir. KolmogorovSmirnov testi sonucunda bağımsız değişkenlerin dağılımlarının normal olduğu ( $p>.05)$ sonucuna ulaşılmıştır. Cinsiyet, sınıfta mülteci öğrenci olup olmama durumu için bağımsız değişken düzeyi iki olduğundan öğretmenlerin mülteci öğrencilere yönelik tutum puan ortalamaları arasındaki farkların önem kontrolü t-testi ile; okul çevresinin bulunduğu sosyoekonomik düzey için bağımsız değişken düzeyi ikiden fazla olduğundan söz konusu değişkenlere ilişkin farkların önem kontrolü tek yönlü varyans analizi ile yapılmıştır. Aritmetik ortalamaların belirlenmesinde puan aralığı 1.001.74 hiç katılmıyorum, 1.75-2.49 biraz katılıyorum, 2.50-3.24 çoğunlukla katılıyorum, 3.25-4.00 tamamen katılıyorum olarak belirlenmiştir.

\section{BULGULAR}

Bu bölümde, araştırma ile elde edilen bulgular araştırmanın alt problemleri doğrultusunda ele alınmaktadır. 
Tablo 1. Mülteci ÖğrenciTutum Ölçeğine (MÖTÖ) ilişkin Betimsel Veriler

\begin{tabular}{llll}
\hline Boyutlar & $\mathrm{N}$ & $\bar{x}$ & ss \\
\hline iletişim & 501 & 3.21 & .57 \\
Uyum & 501 & 2.63 & .63 \\
Yeterlik & 501 & 2.04 & .77 \\
Toplam & 501 & 2.80 & .50 \\
\hline
\end{tabular}

Tablo 1'de öğretmenlerin "Mülteci Öğrenci Tutum Ölçeği"nden iletişim boyutunda 3.21, uyum boyutunda 2.63 , yeterlik boyutunda 2.04 ve ölçek toplamında 2.80 puan aldıkları görülmektedir. Bu durum öğretmenlerin mülteci öğrencilere yönelik tutumlarının iletişim, uyum boyutlarında ve ölçek toplamında çoğunlukla katılıyorum, yeterlik boyutunda biraz katılıyorum düzeyinde yer aldığını göstermektedir.

Tablo 2. Öğretmenlerin Cinsiyetlerine Göre Mülteci Öğrencilere Yönelik Tutumlarına İlişkin t Testi Sonuçları

\begin{tabular}{llllllll}
\hline Boyut & Cinsiyet & $\mathrm{N}$ & $\bar{x}$ & ss & sd & t & $\mathrm{p}$ \\
\hline Iletişim & Kadın & 267 & 3.23 & .54 & 499 & .609 & .543 \\
& Erkek & 234 & 3.19 & .59 & & & \\
Uyum & Kadın & 267 & 2.61 & .66 & 499 & -.750 & .454 \\
& Erkek & 234 & 2.66 & .61 & & & \\
Yeterlik & Kadın & 267 & 1.97 & .76 & 499 & -2.145 & .032 \\
& Erkek & 234 & 2.12 & .78 & & & \\
Toplam & Kadın & 267 & 2.79 & .49 & 499 & -.592 & .554 \\
& Erkek & 234 & 2.81 & .51 & & & \\
\hline
\end{tabular}

Tablo 2 incelendiğinde araştırmaya katılan öğretmenlerin cinsiyetlerine göre mülteci öğrencilere yönelik tutumları iletişim $\left[\mathrm{t}_{(499)}=.609 ; p>.05\right]$, uyum $\left[\mathrm{t}_{(499)}=-.750 ; p>.05\right]$ boyutlarında ve ö/çek toplamında [ $\left.\mathrm{t}_{(499)}=-.592 ; p>.05\right]$ anlamlı bir şekilde farklılaşmadığl; yeterlik $\left[\mathrm{t}_{(499)}=-2.145 ; p<.05\right]$ boyutunda erkek öğretmenler lehine anlamlı bir şekilde farklılaştığı görülmektedir. Bu durum erkek öğretmenlerin kadın öğretmenlere göre mülteci öğrencilere yönelik olarak kendilerini daha yeterli gördükleri biçiminde yorumlanabilir.

Tablo 3. Öğretmenlerin Çalıştıkları Sosyoekonomik Çevreye Göre Mülteci Öğrencilere Yönelik Tutumlarına Iliş̧kin Kruskal Wallis $\mathrm{H}$ testi sonuçları

\begin{tabular}{llllllll}
\hline Boyutlar & Sos düzey & $\mathrm{N}$ & Sıra O. & sd & $\chi^{2}$ & $\mathrm{p}$ & A. Fark \\
\hline iletişim & Alt & 128 & 241.98 & 2 & .748 & .688 & \\
& Orta & 361 & 253.71 & & & & \\
& Yüksek & 12 & 265.63 & & & & \\
\multirow{4}{*}{ Uyum } & Alt & 128 & 236.54 & 2 & 1.896 & .387 & \\
& Orta & 361 & 256.53 & & & & \\
& Yüksek & 12 & 238.71 & & & & \multirow{2}{*}{ Yeterlik } \\
& Alt & 128 & 223.77 & 2 & 6.920 & .031 & \\
& Orta & 361 & 259.15 & & & & \\
\multirow{4}{*}{ Toplam } & Yüksek & 12 & 296.21 & & & & \\
& Alt & 128 & 232.08 & 2 & 3.013 & .222 & \\
& Orta & 361 & 257.12 & & & & \\
& Yüksek & 12 & 268.63 & & & & \\
\hline
\end{tabular}


Tablo 3 incelendiğinde araştırmaya katılan öğretmenlerin çalıştıkları okulun bulunduğu sosyoekonomik çevreye göre iletişim $\left[\chi^{2}=.748 ; p>.05\right]$, uyum $\left[\chi^{2}=1.896 ; p>.05\right]$ boyutlarında ve ölçek toplamında $\left[\chi^{2}=3.013 ; p>.05\right]$ anlamlı bir şekilde farklılaşmadığl; yeterlik $\left[\chi^{2}=6.920 ; p<.05\right]$ boyutunda alt sosyoekonomik çevre ile orta sosyoekonomik çevre karşılaştırıldığında orta sosyoekonomik çevre lehine anlamlı bir şekilde farklılaştığı görülmektedir. Bu durum öğretmenlerin çalıştıkları sosyoekonomik çevrenin yeterlik boyutunda, alt ve orta sosyoekonomik çevre dışında, öğretmenlerin mülteci öğrencilere yönelik tutumlarında bir farklılığa yol açmadığını göstermektedir.

Tablo 4. Öğretmenlerin Sınıflarında Mülteci Öğrenci Olma Durumlarına Göre Mülteci Öğrencilere Yönelik Tutumlarına İlişkin t Testi Sonuçları

\begin{tabular}{llllllll}
\hline Boyut & Mülteci öğr. & $\mathrm{N}$ & $\bar{x}$ & $\mathrm{ss}$ & $\mathrm{sd}$ & $\mathrm{t}$ & $\mathrm{p}$ \\
\hline iletişim & Var & 338 & 3.23 & .54 & 499 & 1.083 & .279 \\
& Yok & 163 & 3.17 & .62 & & & \\
\multirow{4}{*}{ Uyum } & Var & 338 & 2.70 & .62 & 499 & 3.260 & .001 \\
& Yok & 163 & 2.50 & .64 & & & \\
\multirow{4}{*}{ Yoterlik } & Var & 338 & 2.09 & .78 & 499 & 2.147 & .032 \\
& Yok & 163 & 1.93 & .75 & & & \\
& Var & 338 & 2.84 & .48 & 499 & 2.676 & .008 \\
& Yok & 163 & 2.71 & .51 & & & \\
\hline
\end{tabular}

Tablo 4 incelendiğinde araştırmaya katılan öğretmenlerin sınıflarında mülteci öğrenci olup olmama durumlarına göre mülteci öğrencilere yönelik tutumları iletişim $\left[\mathrm{t}_{(499)}=1.083 ; p>\right.$.05] boyutunda

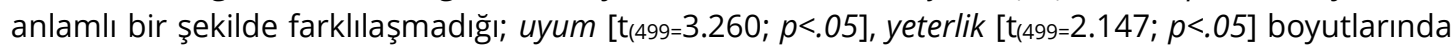
ve ölçek toplamında $\left[\mathrm{t}_{(499)}=2.676 ; p<.05\right]$ sınıfında mülteci öğrenci bulunan öğretmenler lehine anlamlı bir şekilde farklılaştı̆̆ı görülmektedir. Bu sonuç sınıflarında mülteci öğrenci bulunan öğretmenlerin, sınıflarında mülteci öğrenci bulunmayan öğretmenlere göre iletişim boyutu hariç, mülteci öğrencilere yönelik tutumlarına olumlu yansıdığını göstermektedir.

\section{SONUÇ, TARTIŞMA VE ÖNERILER}

Bu bölümde sonuçlar araştırmanın alt problemlerine uygun olarak tartışıımıştır.

\subsection{Sonuç ve Tartışma}

Araştırmaya katılan öğretmenlerin mülteci öğrencilere yönelik tutumlarının iletişim, uyum boyutlarında ve ölçek toplamında çoğunlukla katılıyorum, yeterlik boyutunda biraz katılıyorum düzeyinde yer aldığı sonucuna ulaşılmıştır. Bu durum öğretmenlerin mülteci öğrencilere yönelik tutumlarının yeterlik boyutu dışında kabul edilebilir; yeterlik boyutunda ise arzu edilen düzeyden düşük olduğunu göstermektedir. Bu durum öğretmenlerin mülteci öğrencilere yönelik eğitim almamaları, almışlarsa da mülteci öğrencileri eğitmeye yönelik yeterliklerinin istenilen düzeyde olmamasıyla açıklanabilir. Buradan çok kültürlü yapıya sahip okullarda çalışan öğretmenlerin mülteci öğrencilerin eğitimine yönelik kendilerini yeterli hissetmedikleri sonucu çıkarılabilir. Bu durum alan yazında, göçmen çocukların devam ettiği okullarda görev yapan öğretmen ve idarecilerin karşılaştıkları sorunların incelendiği çalışmalarda, öğretmenlerin kendilerini yetersiz hissettiği durumlarla benzerlik göstermektedir. Nar (2008) göç bölgesinde çalışan öğretmenlerin eğitimde yaşanan olumsuz durumlar sonucunda motivasyonların düştüğünü tespit etmiştir. Baltacı (2014) göç ile gelen öğrencilerin akademik başarılarının arttırılması için gerekli çalışmanın yürütüldüğünü, fakat öğretmenlerin öğrencilere yaptıkları desteğin tek başına yeterli olmadı̆̆ını; Polat ve Rengi (2014) sınıf öğretmenlerinin farklı kültürel özelliklerden gelen öğrencilere nasıl davranılması gerektiği ile ilgili kültürlerarası etkileşimde yetersizlik ve sorun yaşadıklarını belirlemişlerdir. Er ve Bayındır (2015) öğretmenlerin büyük bir çoğunluğunun mülteci çocukların 
eğitimlerine ilişkin herhangi bir eğitimleri olmadığını ve öğretmenlerin büyük bir çoğunluğunun mülteci çocukların eğitimlerini sorunsuz bir şekilde gerçekleştiremeyeceklerine inandıkları belirlemiştir. Sakız (2016) göçmen çocukların eğitiminde, öğretmenlerin mesleki yeterlilik düzeylerinin arttırılması ve farklı koşullarda bulunan çocukların eğitilmesi konusunda öğretmenlere destek verilmesi gerektiği sonucuna ulaşmıştır. Uzun ve Bütün'ün (2016) çalışmalarında sınıflarında sığınmacı öğrenci bulunan okul öncesi öğretmenlerinin, böyle bir durumla daha önce karşılaşmadıkları için sorun çözme konusunda kendilerini yetersiz hissettikleri ve çocuklara nasıl yardımcı olacaklarını bilemediklerini belirtmişlerdir. Eroğlu ve Gülcan'ın (2016) okul yöneticileri ile yaptıkları çalışmada, öğretmenlerin göçle gelen öğrencilerin sorunlarını algılamakta genellikle yeterli olduklarını, ancak yabancı uyruklu öğrencilerin sorunlarını algılamakta zorluklar yaşadıklarını belirlemişlerdir. Balkar, Şahin ve Işıklı- Babahan (2016) Suriyeli öğretmenlerin sığınmacı çocukların eğitiminde, sınıf yönetimi konusunda kendilerini yetersiz hissettikleri ve mesleki gelişim intiyacı duyduklarını belirtmişlerdir. Taştekin, Bozkurt Yükçü, İzoğlu, Güngör, Işık Uslu ve Demircioğlu (2016) öğretmenlerin çok kültürlülüğe ilişkin olumlu bir tutuma sahip olduklarını, ancak sınıf uygulamalarında kendilerini yetersiz hissettiklerini, bunun nedeni olarak da aile ve okul yöneticilerinin tutumları, eğitim müfredatının yetersizliği ve öğretmenlerin yeterli bilgiye sahip olmaması göstermektedirler.

Araştırmaya katılan öğretmenlerin cinsiyetlerine göre mülteci öğrencilere yönelik tutumlarının iletişim, uyum boyutlarında ve ölçek toplamında farklılaşmadığı; yeterlik boyutunda erkek öğretmenler lehine anlamlı bir şekilde farklılaştığı görülmüştür. Bu durum erkek öğretmenlerin kadın öğretmenlere göre mülteci öğrencilere yönelik olarak kendilerini daha yeterli gördükleri biçiminde yorumlanabilir. Bu da, kadın öğretmenlerin mülteci öğrencilerin bulunduğu sınıf ortamlarında çalışırken; sınıf yönetimi konusunda erkek öğretmenlere göre kendilerini yetersiz hissettikleri şeklinde ifade edilebilir. Nar (2008) çalışmasında göç alan okullarda okuyan öğrencilerin ailelerinin kırsal kesimlerden, farklı kültürlerden geldiğini, bu ailelerde kadına yeterince değer verilmediğini ve öğrencilerin kültürel bakış açılarından dolayı kadın öğretmenlerin sınıf yönetiminde zorlandıklarını belirlemiştir. Korkut ve Babaoğlan (2012) Türk kültüründe erkeğe yüklenen değerin, kadına yüklenen değerden daha yüksek olması nedeniyle erkek öğretmenlerin kadın öğretmenlerden daha yüksek öz yeterlik inancına sahip olduğunu tespit etmişlerdir.

Araştırmaya katılan öğretmenlerin çalıştıkları okulun bulunduğu sosyoekonomik çevreye göre iletişim, uyum boyutlarında ve ölçek toplamında anlamlı bir şekilde farklılaşmadığı; yeterlik boyutunda alt sosyoekonomik çevre ile orta sosyoekonomik çevre karşılaştırıldığında orta sosyoekonomik çevre lehine anlamlı bir şekilde farklılaştığı görülmüştür. Bu durum öğretmenlerin çalıştıkları sosyoekonomik çevrenin yeterlik boyutunda alt ve orta sosyoekonomik çevre dışında, mülteci öğrencilere yönelik tutumlarında bir farklılığa yol açmadığını göstermektedir. Yazıcı, Başol ve Toprak (2009) öğretmenlerin okulunun bulunduğu yere göre çok kültürlü eğitime yönelik tutumları arasında anlamlı bir fark olduğunu ortaya koymuşlardır. Özer, Komsuoğlu ve Ateşok (2016) öğretmenlerin çeşitli kültürlerden ve sosyoekonomik şartlardan gelen, travma yaşamış göçmen çocuklara ve desteğe intiyaç duyan öğrencilere nasıl davranılabileceği konusunda yeterliliklerinin geliştirilmesi gerektiğini belirtmişlerdir. Uzun ve Bütün (2016) çalışmalarında sınıflarında sığınmacı öğrenci bulunan bazı okul öncesi öğretmenlerinin, sığınmacıların sosyoekonomik imkânsızlıklardan dolayı temel bakım becerilerini ve intiyaçlarını karşılayamadığını, öğretmen olarak sorunları çözme konusunda kendilerini yetersiz hissettiklerini ifade etmişlerdir. Özözen Danacı, Eran, Çetin, Pınarcık ve Bahtiyar'ın (2016) çalışmalarında merkezde görev yapan öğretmenlerin çok kültürlü eğitime ilişkin tutumlarının, köyde görev yapan okul öncesi öğretmenlere göre daha yüksek olduğu bulunmuştur. Bu durumun il merkezlerinin, köylere göre çok kültürlü sosyal yapıya sahip olması ve büyükşehirlerde görev yapan öğretmenlerin, köyde görev yapan öğretmenlere göre kendilerini çok kültürlü eğitim açısından daha yeterli bulmaları ile ilişsili olduğu düşünülmüştür. 
Araştırmaya katılan öğretmenlerin sınıflarında mülteci öğrenci olup olmama durumuna göre mülteci öğrencilere yönelik tutumlarının iletişim boyutunda farklılaşmadığı; uyum, yeterlik boyutlarında ve ölçek toplamında sınıfında mülteci öğrenci bulunan öğretmenler lehine anlamlı bir şekilde farklılaştığı görülmüştür. Bu sonuç sınıflarında mülteci öğrenci bulunan öğretmenlerin, mülteci öğrencisi olmayan öğretmenlere göre iletişim boyutu hariç, tutumlarına olumlu yansıdığını göstermektedir. Bu durum sınıflarında mülteci öğrenci bulunan öğretmenlerin bu öğrencileri daha yakından tanıma fırsatı buldukları için kendilerini bu yönde geliştirme ve empati kurma eğilimi içinde oldukları şeklinde yorumlanabilir. Maya'ya (2016) göre; kültürel çeşitliliğe duyarlı öğretmenlerin, öğrencileri arasındaki ırk, etnik köken, sosyoekonomik durumlarındaki farklııkları bildiğini ve öğrencilerle iletişim kurarak, onları anlamak için çeşitli yolları denediğini ileri sürmektedir. Polat (2009) yaptığı araştırmada öğretmen adaylarının çok kültürlü eğitim ve kültürel empati boyutlarına, yüksek düzeyde yatkın olduklarını ortaya koymuştur. Bozan (2014), öğretmenlerin görüşlerine dayalı olarak gerçekleştirdiği araştırmasında, göç alan bölgelerde çalışan öğretmenlerin samimi, özverili ve sabırlı olması gerektiğini belirlemiştir. Ereş (2015) okul liderleri ve öğretmenlerin, göçmen çocukların eğitimini desteklemeleri ve duyarlı davranmaları gerektiğini belirtmiştir. Bingöl ve Özdemir (2014) Avrupa ülkelerinde bulunan Türk çocuklarının durumuna yönelik yaptığı araştırmada, göçmen çocukların eğitiminde yapılacak gerekli düzenlemelerle, sınıf ve okullarda kültürlerarası yaklaşımın uygulamaya tam olarak yansıması gerektiğini ifade etmişlerdir. Polat ve Rengi (2014) sınıf öğretmenlerinin kültürel olarak farklı gördükleri öğrencilere ve onların kültürel farklııklarına karşı olumlu duygulara sahip, duyarlı davranış ve tutumlara yatkın olduklarını tespit etmişlerdir. Karatas (2015) öğretmenlerin çok kültürlü eğitime karşı tutumlarının yüksek düzeyde olduğunu, kültürel olarak farklılık gösteren sınıflarda eğitimi kabul ettiklerini ve özen gösterdiklerini ifade etmiştir. Sakız (2016) araştırmasında yeterliliklerinin farkına varan öğretmenlerin, çocukların eğitimine dair olumlu tutumlar geliştirdiğini belirtmiştir. Toprakkaya ve Akdağ (2016) öğretmen adaylarının sığınmacılar ile ilgili görüşlerinde farklı kültürleri tanıma imkanı bulduklarını ve empati kurabildiklerini ifade etmişlerdir. Sarıtaş, Şahin ve Çatalbaş (2016) öğretmen ve yöneticilerin İran, Afganistan, Irak'tan gelen öğrencilerin ve ailelerinin sosyoekonomik ve eğitim düzeyleri yüksek olduğu için sınıfa uyum gösterdikleri ve Türkiye'ye uyum sağladıkları hakkında olumlu görüşlerini belirtmişlerdir. Özdemir'in (2016) çalışmasında ilkokul, ortaokul, liselerde görev yapan öğretmenlerin görüşlerine göre, yabancı uyruklu öğrencilerle karşlıklı olarak olumlu iletişimin kurulduğu, bu öğrencilerin okul iklimi üzerinde olumsuz etkilerinin olmadığı anlaşımıştır. Okul yöneticileri, yabancı uyruklu öğrencilerin geçmişte yaşadıkları olumsuz şartlar noktasında onlarla empati kurduklarını, onları anlamaya, sorunlarını çözmeye gayret gösterdiklerini; ayrım yapmadan, okuldaki diğer tüm öğrencilerle bir tuttuklarını ifade etmişlerdir. Börü ve Boyacı (2016) öğretmenlerin, göçmen öğrencilerin eğitimlerinin niteliğine önem verdikleri, empati kurma yönünde davranışlar gösterdikleri şeklinde görüş bildirmişlerdir. Özözen Danacı, Eran, Çetin, Pınarcık ve Bahtiyar'ın (2016) çalışmalarında okul öncesi öğretmenlerinin çeşitli kültürel farkıııklar ve çok kültürlü eğitime yönelik tutumlarının yüksek olduğunu belirtmişlerdir. Taştekin, Bozkurt Yükçü, İzoğlu, Güngör, Işık Uslu ve Demircioğlu (2016) sınıfında farklı etnik köken ve kültüre sahip öğrencileri bulunan öğretmenlerin farklı kültürleri olan öğrencileri tanıma ve anlama konusunda deneyimlerinden faydalandığını, çok kültürlü eğitime ilişkin tutumlarını ve algılarını olumlu yönde etkilediğini belirtmişlerdir.

Sonuç olarak bu araştırma öğretmenlerin mülteci öğrencilere yönelik tutumlarının iletişim, uyum boyutlarında ve ölçek toplamında çoğunlukla katılıyorum, yeterlik boyutunda biraz katılıyorum düzeyinde yer aldığını göstermektedir. Öğretmenlerin cinsiyetlerine göre mülteci öğrencilere yönelik tutumlarının "yeterlik" boyutunda erkek öğretmenler lehine; okulun bulunduğu sosyoekonomik çevreye göre orta sosyoekonomik çevre lehine; sınıflarında mülteci öğrenci olup olmama durumuna göre "iletişim" boyutu hariç sınıflarında mülteci öğrenci bulunan öğretmenler lehine anlamlı bir şekilde farklılaştığı sonucuna ulaşılmıştır. 


\section{2 Öneriler}

Bu bölümde araştırmanın sonuçlarına dayalı olarak öneriler geliştirilmiştir.

1. Özellikle mülteci öğrencilerin devam ettiği okullarda görev yapan sınıf öğretmenleri mülteci öğrencilerin eğitimine yönelik kendilerini yeterli hissedebilmeleri ve geliştirebilmeleri için hizmet içi eğitim verilmesi sağlanmalıdır.

2. Kadın öğretmenlerin mülteci öğrencilerin eğitiminde kendilerini yeterli hissetmeleri yönünde çalışmalar yapıımalıdır. Mülteci çocukların eğitiminde erkek öğretmenlerin kendilerini kadın öğretmenlere göre daha yeterli hissettiğinin görülmesi; kadın öğretmenlerin bu konuda desteklenmesini gerektirmektedir.

3. Öğretmen adayları mülteci öğrencilerin eğitimine yönelik olarak hizmet öncesinde eğitilmeli, öğretmenlik uygulamaları kapsamında Geçici Eğitim Merkezleri ve mülteci öğrenci bulunan devlet okullarında deneyim kazanmaları sağlanmalıdır.

4. Alt ve orta seviyedeki sosyoekonomik çevrede görev yapan öğretmenlerin mülteci öğrencilerin eğitimlerinde kendilerini yeterli hissedebilmeleri için; bulundukları çevrenin değer yargılarının mülteci çocuklar üzerindeki etkilerini fark edebilmeleri gerekmektedir. Öğretmenler mülteci çocuklarla empati kurma, özverili davranmaları için; hizmet içi eğitimlerle desteklenmeli ve mülteci öğrencilerin sorunlarının çözümüne yönelik okul idaresi ve rehber öğretmenlerle işbirliği içerisinde olmalıdır. Hizmet içi eğitimlerde, göç alan yerlerdeki çocukların eğitimi, sorunların tespiti ve çözümlerinde öğretmenlerin bilgilendirilmesi için akademik çalışmalardan faydalanılmalıdır.

5. Sınıfında mülteci öğrenci bulunan öğretmenlerin deneyimleri, duyguları ve sınıf yönetimi hakkındaki görüşleri, mülteci öğrencilere yaklaşımları, sınıflarında mülteci öğrenci bulunmayan öğretmenlerle paylaşılmalıdır. Sınıflarında mülteci öğrenci bulunan öğretmenlerin, okulda mülteci öğrencilerin ihtiyaçlarının karşılanmasına yönelik yapılan çalışma ve etkinliklerde gönüllü olarak yer almaları, Geçici Eğitim Merkezlerinde çalışan öğretmenlerle birlikte seminer yaparak bilgi paylaşımında bulunmaları, mülteci öğrencileri tanıma ve empati kurabilmelerinin sağlanması bakımından önemlidir.

\section{Kaynakça}

Akşit, G., Bozok, M. ve Bozok, N. (2015). Zorunlu göç, sorunlu karşılaşmalar: hisar köyü, nevşehir'deki suriyeli göçmenler örneği. Maltepe Üniversitesi Fen-Edebiyat Fakültesi Dergisi, 1(2), 92-116.

Apak, H. (2014). Suriyeli göçmenlerin kente uyumları: Mardin örneği. Mukaddime, 5(2), 53-70.

Baltacı, H. (2014). Göçmen öğrencilerin başarı durumunu etkileyen etmenlerin okul yöneticisi, öğretmen, veli ve öğrencilerin görüşlerine göre değerlendirilmesi. Yayımlanmamış yüksek lisans tezi, Yakın Doğu Üniversitesi, Eğitim Bilimleri Enstitüsü, Kıbrıs.

Balkar, B., Şahin, S. ve Işıklı Babahan, N. (2016). Geçici eğitim merkezlerinde (GEM) görev yapan suriyeli öğretmenlerin karşılaştıkları sorunlar. Eğitimde Kuram ve Uygulama, 12(6), 1290-1310.

Beter, Ö. (2006). Sınırlar Ötesi Umutlar, Mülteci Çocuklar. Ankara: SABEV Yayınları.

Bingöl, A. S. ve Özdemir, M. Ç. (2014). Almanya ve Hollanda'da Türk Göçmen işçi çocuklarına uygulanan eğitim politikaları. Türk Eğitim Bilimleri Dergisi, 12(2), 134-157.

Büyüköztürk, Ş. (2009). Sosyal Bilimler İçin Veri Analizi El Kitabı. Ankara: Pegem A Yayıncılık.

Bozan, í. (2014). Türkiye'de iç göç hareketleri ve göçün eğitim üzerindeki etkisi: Bir durum çalışması. Yayımlanmamış yüksek lisans tezi. Akdeniz Üniversitesi Eğitim Bilimleri Enstitüsü, Antalya.

Börü, N. ve Boyacı, A. (2016). Göçmen öğrencilerin eğitim-öğretim ortamlarında karşılaştıkları sorunlar: Eskişehir ili örneği. Electronic Turkish Studies, 11(14), 123-158. 
Deniz, O. ve Yıldız, M. Z. (2016). 2011 depreminin Van kentindeki sığınmacılar üzerine etkisi. Doğu Coğrafya Dergisi, 21(35), 63-74.

Er, A. R. ve Bayındır, N. (2015). illkokula giden mülteci çocuklara yönelik sınıf öğretmenlerinin pedagojik yaklaşımları. Uluslararası Sosyal ve Eğitim Bilimleri Dergisi, 2(4), 175-185. DOl: 10.20860/ijoses.08223

Ereş, F. (2015). Türkiye'de göçmen eğitimi sorunsalı ve göçmen eğitiminde farklılığın yönetimi. Çankırı Karatekin Üniversitesi Sosyal Bilimler Enstitüsü Dergisi, 6(2), 17-30.

Eroğlu Ö. B. ve Gülcan, G. M. (2016). Göçle gelen ailelerin ve çocuklarının eğitim sorunları (Mersin İli Örneği). K. Beycioğlu, N. Özer, D. Koşar, İ. Şahin (Ed.), Eğitim Yönetimi Araştırmaları içinde (ss. 219-238). Ankara: Pegem Akademi. 1. Baskı. DOl: 10.14527/978-605-318-393-8.

Güneş, M. (2013). Uluslararası göçün tetikleyicileri; Suriye'den Türkiye'ye zorunlu göçün Cilvegözü örneği ile yansımaları. Yayımlanmamış yüksek lisans tezi. Turgut Özal Üniversitesi Sosyal Bilimler Enstitüsü, Ankara.

Karasar, N. (2005). Bilimsel Araştırma Yöntemleri. Ankara: Nobel Yayın Dağııım.

Karatas, S. (2015). Teachers' views on multicultural education: Sample of Antalya. Anthropologist, 19(2), 373-380.

Kılcan, B., Çepni, O. ve Kılınç, A. Ç. (2017). Mülteci öğrencilere yönelik tutum ölçeğinin geliştirilmesi. Journal of Human Sciences, 14(2), 1045-1057. DOI: 10.14687/jhs.v14i2.4324

Kıratlı, T. (2011). Mülteci ve sığınmacıların toplumsal görünümü (Türkiye Örneği). Yayımlanmamış yüksek lisans tezi. Süleyman Demirel Üniversitesi Sosyal Bilimler Enstitüsü, Isparta.

Korkut, K. ve Babaoğlan, E. (2012). Sınıf öğretmenlerinin öz yeterlik inançları. Ulus/ararası Yönetim iktisat ve işletme Dergisi, 8(16), 269-282.

Körükmez, L. ve Südaş, i. (2015). Göçler Ülkesi. İstanbul: Ayrıntı Yayınları.

Maya, i. (2016). illkokul ve ortaokul öğretmenlerinin çok kültürlü sınıf ortamlarında sınıf yönetiminde karşılaştıkları sorunlar ve bu sorunlar için kullandıkları stratejiler. K. Beycioğlu, N. Özer, D. Koşar, İ. Şahin (Ed.), Eğitim Yönetimi Araştırmaları içinde (ss. 428-434). Ankara: Pegem Akademi. 1. Baskı. DOI: 10.14527/978-605-318-393-8.

Mercan Uzun, E. M. ve Bütün, E. (2016). Okul öncesi eğitim kurumlarındaki suriyeli sığınmacı çocukların karşılaştıkları sorunlar hakkında öğretmen görüşleri. Uluslararası Erken Çocukluk Eğitimi Çalışmaları Dergisi, 1(1),72-83.

Nar, B. (2008). Göçün eğitime ve eğitim yönetimine etkileri (Dilovası örneği). Yayımlanmamış yüksek lisans tezi. Sakarya Üniversitesi, Sosyal Bilimler Enstitüsü, Sakarya.

Özdemir, Ç. (2016). Sivas ilinde öğrenim gören yabancı uyruklu öğrencilerin okul iklimine etkisine ilişkin görüşlerin incelenmesi. Yayımlanmamış yüksek lisans tezi. Cumhuriyet Üniversitesi, Eğitim Bilimleri Enstitüsü, Sivas.

Özer, Y. Y., Komsuoğlu, A. ve Ateşok, Z. Ö. (2016). Türkiye'deki Suriyeli çocukların eğitimi: Sorunlar ve çözüm önerileri. Akademik Sosyal Araştırmalar Dergisi, 4(37), 76-110.

Özözen Danacl, M., Eran, N., Çetin, Z., Pınarcık, Ö. ve Bahtiyar, M. (2016). Okul öncesi öğretmenlerinin çok kültürlü eğitime yönelik tutumları. Hacettepe Üniversitesi Sağlık Bilimleri Fakültesi Dergisi, 3(2), 73-86.

Polat, S. (2009). Öğretmen adaylarının çok kültürlü eğitime yönelik kişilik özellikleri. International Online Journal of Educational Sciences (Joses), 1(1), 154-164.

Polat, S. ve Rengi, Ö. (2014). Sınıf öğretmenlerinin kültürel farklılık algıları ve kültürlerarası duyarlılıkları. Zeitschrift für die Welt der Türken Journal of World of Turks, 6(3), 135-156.

Sakız, H. (2016). Göçmen çocuklar ve okul kültürleri: Bir bütünleştirme önerisi. Göç Dergisi, 3(1), 6581. 
Sarıtaş, E., Şahin, Ü. ve Çatalbaş, G. (2016). Illkokullarda yabancı uyruklu öğrencilerle karşılaşılan sorunlar. Pamukkale Üniversitesi Sosyal Bilimler Enstitüsü Dergisi, 25(1), 208-229.

Taştekin, E., Bozkurt Yükçü, Ş., İzoğlu, A., Güngör, i., Işık Uslu, E. A. ve Demircioğlu, H. (2016). Okul öncesi öğretmenlerinin çokkültürlü eğitime yönelik tutumlarının ve algılarının incelenmesi. Hacettepe Üniversitesi Eğitim Bilimleri Enstitüsü Eğitim Araştırmaları Dergisi (HÜNER), 2(1), 1-20.

Topkaya, Y. ve Akdağ, H. (2016). Sosyal bilgiler öğretmen adaylarının suriyeli sığınmacılar hakkındaki görüşleri. Çankırı Karatekin Üniversitesi Sosyal Bilimler Enstitüsü Dergisi, 7(1), 767-786.

Türkiye Büyük Millet Meclisi İnsan Haklarını İnceleme Komisyonu [TBMMiHiK], (2013). Ülkemize sığınan Suriye vatandaşlarının barındıkları çadırkentler hakkında inceleme rapor-3. http://docplayer.biz.tr/13080179Ulkemize-siginan-suriye-vatandaslarinin barindiklari cadirkentler-hakkinda-inceleme-raporu-3.html adresinden 11.10.2016 tarihinde erişim sağlanmıştır.

Birleşmiş Milletler Uluslararası Çocuklara Yardım Fonu [UNICEF], (2016). Türkiye'de Kayıp Bir Kuşak Oluşmasını Önlemek. http://www.unicefturk.org/public/uploads/files/10.2016 Children\%20of\%20Syria_revised_TR.pdf adresinden 20.01.2017 tarihinde erişilmiştir.

Tunç, A. Ş. (2015). Mülteci davranışı ve toplumsal etkileri: Türkiye'deki Suriyelilere ilişkin bir değerlendirme. Tesam Akademi Dergisi, 2(2), 29-63.

Ünal, S. (2014). Türkiye'nin beklenmedik konukları: "Öteki" bağlamında yabancı göçmen ve mülteci deneyimi. Zeitschriftfürdie Welt der Türken Journal of World of Turks, 6(3), 65-89.

Yazıcı, S., Başol, G. ve Toprak, G. (2009). Öğretmenlerin çok kültürlü eğitim tutumları: Bir güvenirlik ve geçerlik çalışması. Hacettepe Üniversitesi Eğitim Fakültesi Dergisi, 37, 229-242.

Zolberg, A. R. ve Benda, P. M. (2001). Global migrants, global refugees: Problems and solutions. New York: Berghahn Books. 


\section{Extended Summary}

Throughout history, it is known that people have migrated to different geographical regions for different reasons. Migrations play an important role in the political, social, economic and cultural impacts of societies (Ünal, 2014; Apak, 2014). Turkey has been one of the most immigrant-receiving country in history due to its geographical location (Kıratli, 2011). Since the end of the 1970s, there have been international migrations to Turkey, particularly those with border countries, such as asylum seekers, refugees, transit migrants and illegal workers (Güneş, 2013). Turkey is under the influence of a new international migration movement originating from Syria (Kıratll, 2011). The conflicts in Syria and forced migrations were the most affected children. In addition to the psychological trauma they experience, children are exposed to a wide range of risks, including social discrimination, economic and sexual exploitation, child marriages, and have become seriously vulnerable (United Nations International Children's Fund [UNICEF], 2016). Primary education has an important place in human life. In this respect, the education of the refugee students who continue their lives in Turkey and are in the age of primary school has of great importance. It is closely related to the attitudes and attitudes of the teachers that refugee students can adapt to their classes and get rid of the negativity. In this sense, important tasks and responsibilities belong to the classroom teachers who work in primary schools. It is closely related to the attitudes of the classroom teachers that refugee students who have had a long history are able to keep alive and to feed love for the country they live in, in this period when the basic knowledge and skills are learned and the infrastructure of complex learning is established. It was thought that this research was different from the studies in question, since there were no studies on the attitudes of classroom teachers to the refugee students, which could be described as parents in the school. Therefore, the main objective of the study was to examine the attitudes of classroom teachers towards refugee students according to various variables. It was also aimed to determine whether the attitudes of class teachers to refugee students differed according to gender, the socioeconomic environment in which they worked, and whether or not there were refugee students in their class.

\section{Method}

This study was conducted by comparison type relational survey model. Sample of the study was consist of total number of 501 class teachers, who 267 of them were women (53\%) and 234 of them were (47\%) male working in the province of Sakarya in the academic year 2016-2017.

\section{Data Collection Tool}

"Refugee Student Attitude Scale (RSAS)" which consist of three sub-dimensions and 24 items used as a data collection tool. The sub-dimensions of the scale were "communication", "adaptation", "efficiency". Internal consistency coefficient of your scale (Alpha) .91; the first sub-dimension is .88, the second sub-dimension is .88 , and the third sub-dimension is .80 .

\section{Results and Discussions}

The attitudes of the teachers participating in the research to the refugee students were strongly agree in the dimensions of communication, adaptation dimensions and scale, and they were agree at the level of proficiency. This can be considered outside of the competence dimension of teachers' attitudes towards refugee students; While in the case of qualification it is lower than the desired level. Er and Bayındır (2015) found that a large majority of teachers did not have any training on refugee children's education and that a large majority of teachers believed that they would not be able to perform the education of refugee children without problems.

According to the gender of the teachers participating in the research, the attitudes towards the refugee students did not differ in the communication, adaptation dimension and scale sum; In terms of qualification, significantly differentiated in favor of male teachers. This situation can be interpreted in the way that male teachers see themselves more adequately for refugee students 
than female teachers. This means that while female teachers are working in classrooms where refugee students are located, It can be expressed that they felt themselves inadequate in classroom management compared to male teachers. Korkut and Babaoğlan (2012) found that male teachers had higher self-efficacy beliefs than female teachers because the value placed on man in Turkish culture was higher than the value put on woman.

According to the socioeconomic environment in which the teachers who participated in the study did not differ significantly in communication dimension, adjustment dimension and whole scale. When compared to the low socioeconomic environment and the middle socioeconomic environment in terms of the competence dimension, it appears that they differ significantly in favor of the middle socioeconomic environment.

Uzun and Bütün (2016) reported that some pre-school teachers with asylum-seeking students in their class felt that they were unable to meet basic care skills and needs due to socioeconomic difficulties and that they were inadequate as teachers to solve problems.

According to the results attitudes of refugee students to the refugee students in the classes of the surveyed teachers did not differ in the communication dimension; Compliance, proficiency dimensions and scale totally differentiate favorably for teachers with refugee students in their class. This result shows that teachers who have refugee students in their classes are positively reflected in their attitudes, except communication dimension, compared to teachers who don't have refugee students in their classes. This findings can be interpreted as the fact that teachers with refugee students in their class have a tendency to develop and empathize with them because they have a chance to get to know these students more closely. Toprakkaya and Akdağ (2016) stated that teacher candidates have the opportunity to recognize different cultures and empathize in their views on asylum seekers. Börü ve Boyacı (2016) stated that teachers expressed the importance of emphasizing the nature of the education of immigrant students and showing behavior towards empathy. 


\section{Ek-1: Mülteci Öğrenci Tutum Ölçeği (MÖTÖ)}

\begin{tabular}{|c|c|c|c|c|c|c|}
\hline 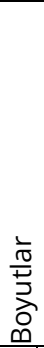 & $\begin{array}{l}\frac{\bar{d}}{d} \\
\frac{D}{0} \\
\frac{0}{0} \\
\Sigma\end{array}$ & $\begin{array}{l}\text { Aşağıda, mülteci öğrencilere yönelik tutumlarla ilgili görüşleriniz } \\
\text { sorulmaktadır. Bu konudaki görüşünüzü, "Hiç katılmıyorum", "Biraz } \\
\text { katılıyorum", "Çoğunlukla katılıyorum", "Tamamen katılıyorum" } \\
\text { maddelerinden size en uygun olanını }(\mathrm{X}) \text { işaretiyle işaretleyerek belirtiniz. }\end{array}$ & 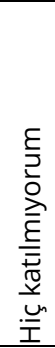 & 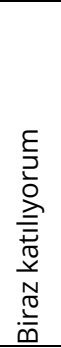 & 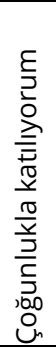 & 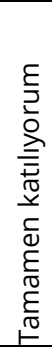 \\
\hline \multirow{11}{*}{$\begin{array}{l}\frac{c}{w n} \\
.0 \\
.0 \\
.0\end{array}$} & 1 & Mülteci öğrencilere önyargısız yaklaşırım & $($ ) & ( ) & ( ) & ( ) \\
\hline & 2 & Uyumda güçlük yaşayan mülteci öğrencilere hoşgörülü davranırım & ( ) & ( ) & ( ) & ( ) \\
\hline & 3 & Mülteci öğrencileri anlamaya çalışırım & $($ ) & ( ) & ( ) & ( ) \\
\hline & 4 & Mülteci öğrencilere yeteri kadar zaman ayırmaya çalışırım & ( ) & ( ) & ( ) & ( ) \\
\hline & 5 & Mülteci öğrenciler için yapılan eğitim hizmetlerini desteklerim & ( ) & $($ ) & ( ) & ( ) \\
\hline & 6 & Mülteci öğrencilere diğer öğrencilere davrandığım gibi davranırım & ( ) & ( ) & ( ) & ( ) \\
\hline & 7 & Mülteci öğrencilerin derslere motive olmaları için çaba gösteririm & ( ) & ( ) & ( ) & ( ) \\
\hline & 8 & Öğrencilerimin mülteci öğrencilere olumlu davranmalarını sağlarım & $($ ) & $($ ) & ( ) & ( ) \\
\hline & 9 & Mülteci öğrencilerin temel bakım becerilerini geliştirmelerini desteklerim & ( ) & ( ) & ( ) & ( ) \\
\hline & 10 & Öğrenciler mülteci öğrencilerle birlikte oyun oynarlar & $($ ) & ( ) & ( ) & ( ) \\
\hline & 11 & Mülteci öğrencilerin eğitimi konusunda kendimi geliştiririm & $($ ) & ( ) & ( ) & ( ) \\
\hline \multirow{9}{*}{$\overbrace{}^{\frac{\varepsilon}{2}}$} & 12 & Mülteci öğrencilere diğer öğrencilerin aileleri olumlu tutum sergiler & ( ) & ( ) & ( ) & ( ) \\
\hline & 13 & Mülteci öğrencilerin temel intiyaçları karşılanır & ( ) & ( ) & ( ) & ( ) \\
\hline & 14 & Öğrenciler mülteci öğrencilerle birlikte olmaktan memnundur & $($ ( ) & ( ) & ( ) & ( ) \\
\hline & 15 & Mülteci öğrenciler düzenli olarak okula devam etmektedir & ( ) & ( ) & $($ ) & $($ ) \\
\hline & 16 & Mülteci öğrencilere ayırdığım zaman yeterlidir & ( ) & ( ) & ( ) & ( ) \\
\hline & 17 & Mülteci öğrenciler okula uyumludur & ( ) & ( ) & ( ) & ( ) \\
\hline & 18 & Mülteci öğrenciler sınıfa uyumludur & ( ) & ( ) & ( ) & ( ) \\
\hline & 19 & Öğrenciler, mülteci öğrencilere karşı olumlu davranış sergiler & ( ) & ( ) & ( ) & $(\mathbf{1})$ \\
\hline & 20 & Mülteci öğrencilere rehberlik yapmaya, yol göstermeye çalışırım & $($ ) & ( ) & $($ ) & $($ ) \\
\hline \multirow{4}{*}{ 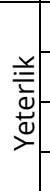 } & 21 & Mülteci öğrencilerin sınıfa uyum sağlamasını kolaylaştırırım & ( ) & ( ) & ( ) & ( ) \\
\hline & 22 & Mülteci öğrencilerle iletişim kurmakta zorlanmam & ( ) & ( ) & ( ) & $($ ( ) \\
\hline & 23 & Mülteci öğrencilerin eğitiminde yeterli olduğumu düşünürüm & ( ) & ( ) & ( ) & ( ) \\
\hline & 24 & Mülteci öğrencilerin dil farklılığı benim için sorun oluşturmaz & ( ) & ( ) & ( ) & ( ) \\
\hline
\end{tabular}

